\title{
DESIGN USING SPECIAL STEEL SHEET PROFILES - PROCEDURES DEVELOPED WITHIN THE FRAMEWORK OF GRISPE AND GRISPE PLUS PROJECTS
}

\author{
M. MASLAK ${ }^{1}$, M. PAZDANOWSKI ${ }^{2}$
}

\begin{abstract}
New computational procedures developed within the framework of international research projects „Grispe” and „Grispe Plus” are briefly presented and characterised here. Considered algorithms pertain to the verification of bearing capacity and serviceability of selected bearing structure components erected with especially shaped thinwalled sheet metal panels. Structural components of this type are so far rather absent from the codes, and as a result the unequivocal design requirements have not been developed for them. Key problems related to the detailed analysis of the following element classes: steel decks with embossments, indentations and/or outwards stiffeners; liner trays; corrugated sheeting; curved profiles; cladding and roof profile assemblies; perforated and holed profiles; external interlocking planks and their assemblies are indicated in the text. The procedures formulated as a part of the projects indicated above have been delivered to CEN as an official proposal of amendments and/or additions submitted for introduction to the new generation of Eurocodes currently under preparation, and especially as an extension to the code EN 1993-1-3.
\end{abstract}

Keywords: thin-walled steel sheet profiles, amendments and additions to the standards, moment resistance, susceptibility to deformations, profile assemblies, embossments and/or indentations, holes and/or perforation, interlocking planks.

\footnotetext{
${ }^{1}$ DSc., PhD., Eng., prof. CUT, Cracow University of Technology, Faculty of Civil Engineering, Warszawska 24, 31-155 Cracow, Poland, e-mail: mmaslak@pk.edu.pl

${ }^{2} \mathrm{PhD}$., Eng., Cracow University of Technology, Faculty of Civil Engineering, Warszawska 24,

31-155 Cracow, Poland, e-mail: michal@15.pk.edu.pl
} 


\section{INTRODUCTION}

The name „Grispe Plus” stands for an acronym of an international research grant „Valorisation of knowledge for specific profiled steel sheets", financed by the European Union for 18 months within the Research Fund for Coal and Steel (grant agreement RFCS-2016 No 754092). This project formally was a continuation of the preceding „Grispe” project, conducted during 2013-2016 under the name "Guidelines and recommendations for integrating specific profiled steel sheets in the Eurocodes". The basic objective of the cooperation within the framework of both projects was to propose authoritative design methods pertaining to seven classes of thin-walled steel elements so far rather absent from normalization. This cooperation was especially oriented on: steel decks with embossments, indentations and/or outwards stiffeners; liner trays; corrugated sheeting; curved profiles; cladding and roof profile assemblies; perforated and holed profiles; external interlocking planks and their assemblies. An appropriate computational procedure has been developed for each of the considered classes and submitted for approval and introduction to the new version of the code EN 1993-1-3. Both projects were coordinated by:

- L'Enveloppe Metallique du Batiment (Paris, France) - society representing French manufactures of steel sections and steel clad layered panels.

In addition the following entities cooperated actively in the „Grispe Plus” project:

- Bacacier (Aigueperse, France) - French manufacturer and exporter of steel profiled panels,

- Joris Ide (Zwevezele, Belgium) - international group of companies making steel roof coverings and wall cladding systems used in buildings,

- Sokol Palisson Consultants (Paris, France) - French design and consulting office specialising in expert appraisals within the domain of steel structures,

- Cracow University of Technology (Cracow, Poland),

- RWTH Aachen University (Aachen, Germany) - leading technical university of Rhineland Westphalia,

- Universita di Pisa (Pisa, Italy) - Italian university grounded in 1343,

- Tampere University of Technology (Tampere, Finland) - renowned Finnish technical university.

Five scientific seminars have been organized within the framework of this project, one in each country participating in the program. The first seminar took place in Paris on October $5^{\text {th }}, 2017$, the following ones were organized on January $23^{\text {rd }}, 2018$ in Aachen, on March $15^{\text {th }}, 2018$ in Pisa, on June $14^{\text {th }}, 2018$ in Cracow and on November 21 $1^{\text {st }}, 2018$ in Helsinki. The participants included 
employees of technical universities as well as designers and erectors interested in the presented agenda. Members of branch organizations and societies have been represented in great number as well.

The conclusions and recommendations prepared within the framework of this project and pertaining to each class of considered profiles are briefly presented in this paper. The detailed results and descriptions of proposed computational procedures may be found in the comprehensive report [1] and [2] prepared for the participants of Cracow meeting [3]. For readers convenience this report has been split into two parts. The first part, per authors agreement, consists of presentations delivered during the lectures and accompanied by more general elaborations containing state of the art knowledge. The second part contains so called design manuals translated into Polish, prepared separately for each type of profile considered in the project and associated computational procedures recommended for practical application. The original English versions of these manuals and their translations into French, German and Italian may be found on the web page www.grispeplus.eu. Additional materials, which may be of use during design, such as for instance spreadsheets referred to in several design manuals, may also be found there.

\section{STEEL DECKS WITH EMBOSSMENTS, INDENTATIONS AND/OR OUTWARDS STIFFENERS}

Thin-walled panels made of profiled steel plates with additional longitudinal indentations or circular embossments (Fig. 1a), or external dovetail shaped flange stiffeners (Fig. 1b) are nowadays widely used, in general as an integral part of composite slab plates. It is stated in the code EN 1994-1-1 [4] that the plates of this type should be designed conforming to the provisions specified in the code EN 1993-1-3 [5]. However, this code does not contain any provisions regarding the treatment of local stiffeners when the characteristics of effective cross section are determined.

a)
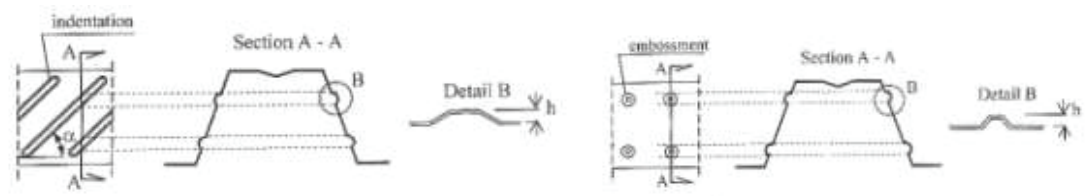
b)

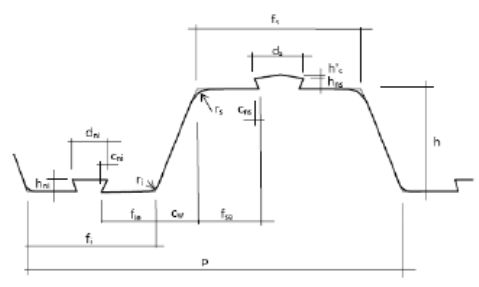

Fig. 1. Profiled sheet metal panel with additional local stiffening of the walls, including: a) longitudinal indentations at left, circular embossments at right, b) dovetail shaped outwards stiffeners.

In the recommendations prepared within the „Grispe” and „Grispe Plus” projects it is proposed to determine the effective cross section in the case of panels with indentations or embossments in a manner analogous to the corresponding panels devoid of indentations and embossments, provided that in the zone of indentations or embossments computational thickness of the panel be reduced by a factor $\rho=A h+B$, where $h$ stands for the depth of the indentation or embossment and the factors $A$ and $B$ depending on the sheet thickness and indentation or embossment type are calibrated experimentally. Detailed values of these factors are listed in [1] and [2]. It has been shown as well that the influence of indentations or embossments of this type may be disregarded when panel is checked against web crippling. When dovetail shaped stiffeners are considered, an assumption on the stress level in the stiffener equal to the stress level in the flange of which the stiffener is made is recommended for application.

\section{LINER TRAYS}

The rules for iterative design of liner trays made of thin-walled profiled steel sheets and applied in modern lightweight cladding systems are given in point 10.2 of EN 1993-1-3 [5]. However, the applicability of this approach has been limited to the situations, when the fixing distance between the outer shell and the narrow flange does not exceed $s_{1}=1000 \mathrm{~mm}$ (Fig. 2). But the experimental research performed in this domain indicated, that the proposed approach is overly conservative. In addition, due to the increasing architectural and thermal requirements liner trays with significantly larger distance between the fasteners are applied more frequently. The problem with an increased fixing distance lies in the reduction of shear stiffening by the outer shell. 

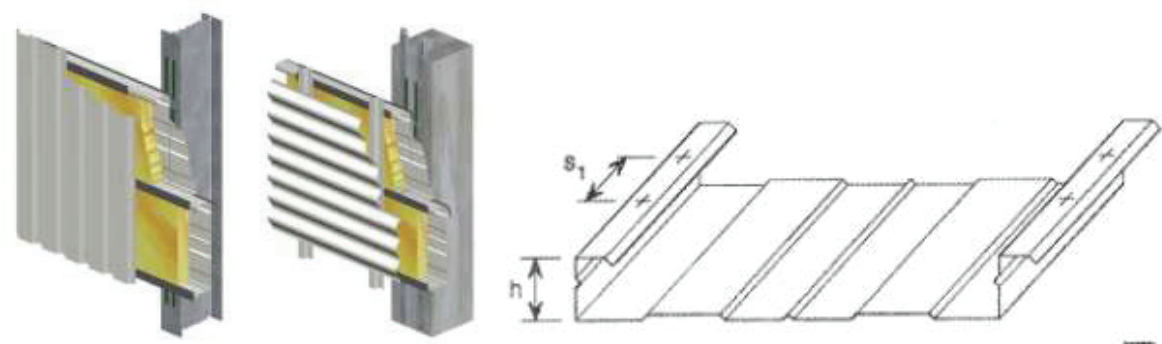

Fig. 2. Typical lightweight cladding systems using liner trays. Location of fixing distance $s_{1}$ on flanges of a single tray at right.

In the code approach the influence of fixing distance $s_{1}$ on buckling resistance of the liner tray in bending $M_{b, R d}$ is expressed by the reduction coefficient $\beta_{b}$. Within the framework of "Grispe" and „Grispe Plus” projects new formulae have been developed, allowing for determination of this coefficient at the distance $s_{1} \leq 2000 \mathrm{~mm}$.

\section{CORRUGATED SHEETING}

In spite of the fact that the corrugated steel sheets of sinusoidal wave type (Fig. 3) belong to the basic types of profiled steel sheets applied in engineering practice, the code EN 1993-1-3 [5] so far lacks clear guidelines regarding the determination of bending resistance $M_{c, R k}$ in the span section, i.e. between the supports of sheathing made of this sheet type. The experimental investigations conducted within the framework of „Grispe” and „Grispe Plus” projects led to formulation of computational procedure allowing for estimation of this resistance. Susceptibility of the sheet metal to the local loss of stability in the compressed area of the cross section is the key issue here.

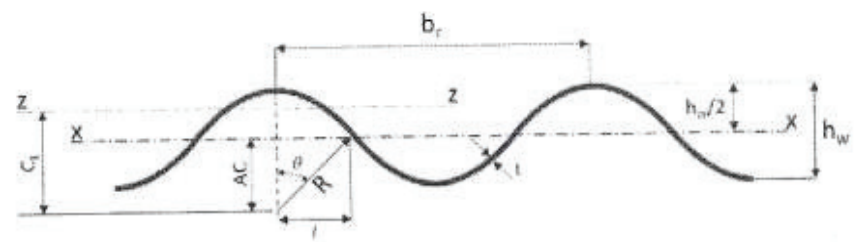

Fig. 3. Characteristics of the corrugated panel cross section. 
It has been shown that two alternative computational scenarios are possible. The first one occurs when $R / t \leq 0,04 E / f_{y b}$ ( $R$ stands for the single fold radius of curvature, while $t$ denotes sheet thickness). In such situation there is no risk of local instability in bending, and therefore the bearing capacity of a sheet may be determined using the formula $M_{c, R k}=W_{y} f_{y b}$. But if $R / t>0,04 E / f_{y b}$, the risk of stability loss is real and the bearing capacity of a sheet metal panel should be determined using the reduced compressive stress $\sigma_{c}$, depending on panel slenderness. Thus in this case $M_{c, R k}=W_{y} \sigma_{c}$. The procedure to determine the $\sigma_{c}$ stress level, advised for application in this case, is based on the regulations contained in the code StBK-N5 [6]. In special cases a simplified computational approach formulated in the code EN 1993-4-1 [7] is allowed for practical use.

\section{CURVED PROFILES}

Computational procedures developed for symmetrically loaded curved panels made of profiled steel sheets within the framework of „Grispe” and „Grispe Plus” projects pertain to two qualitatively different design scenarios. The first scenario is related to the case where both supports are completely unrestrained in the horizontal direction and as a result the arch is subjected to pure bending. The second scenario relates to the case when the horizontal displacements of the supports are restrained, and this as a consequence results in an interaction of bending and axial force in the considered panel. It is proposed, if the considered panel is subjected to pure bending only, to determine its bearing capacity conservatively at the level of $90 \%$ of bearing capacity of corresponding flat panel. However, should there in the arc an interaction of bending and compression occur, an interaction formula listed in the code DIN 18807-1 [8] is suggested for application. The difference between the conventional analysis of this type, related to flat panels, lies in the fact, that in the case of arched panels the coefficient $\alpha$ present in this formula should not be limited to the range of $\alpha \leq 1,0$. It is also important to sufficiently precisely estimate the susceptibility of supports to horizontal displacements beforehand. Overestimating the degree of restraint in horizontal displacement may result in dangerous overestimation of real panel bearing capacity. The proposed procedure may be applied only for curved panels obtained through a continuous roll forming process. 


\section{CLADDING AND ROOF PROFILE ASSEMBLIES}

In the conventional computational procedure it is usually assumed that the panels are joined into a continuous setup over supports, but without taking into account the real increase in bearing capacity in these cross sections due to application of appropriate overlaps. The code EN 1993-1-3 [5] lacks clear guidelines indicating the recommended procedures for verification of such joints. The recommendations of this type are contained in the code DIN 18807-3 [9] instead, though they pertain to only two particular types of these joints, i.e. the „DIN joint” with cantilevered end of profile on top (Fig. 4a) and the „DIN joint” with cantilevered end of profile underneath (Fig. 4b), respectively. The research performed within the framework of „Grispe” and „Grispe Plus” projects allowed for preparation of more general rules for the design of such joints. Additionally analogous rules applicable to widely used joints with double overlap, especially to the so called ,overlap joint” (Fig. 5a) and to the continuous profile with local reinforcement including additional overlapped strip of profiled sheet (Fig. 5b) have been formulated as well.

a)

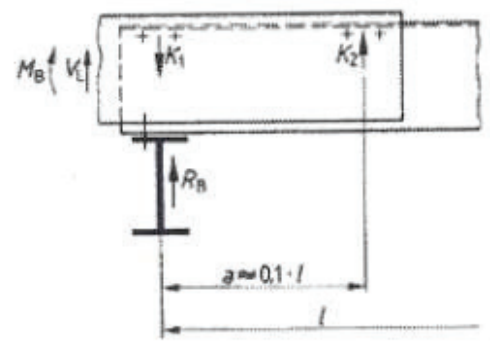

Fig. 4. Single overlap profiled steel sheets joint (the so called ,DIN joints”), including: a) joint with cantilevered end of profile on top, b) joint with cantilevered end of profile underneath.

a)

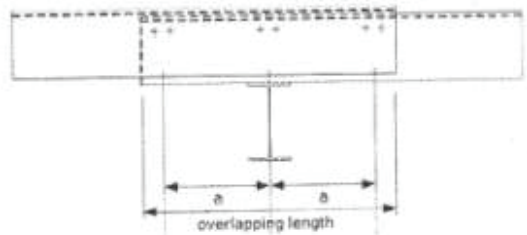

b)

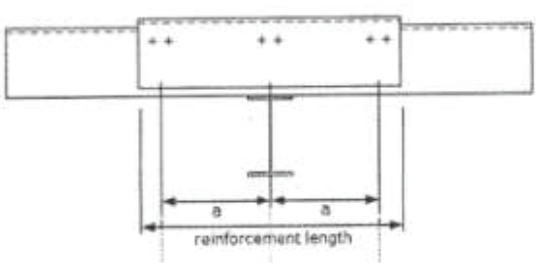

Fig. 5. Double overlap and local reinforcement steel sheet joints, including: a) double overlap joint, b) continuous profile with local reinforcement. 
Verification of the bearing capacity for each of these joints, specified for the continuous setup, must take into account the interaction between the bending moment and the shearing force, the capability of an appropriate fastener group to resist the applied loads and the potential risk of web crippling in the single panel at its cantilevered end [1], [2]. In the proposed computational approach, referring to both joints described in the code [9], i.e. to the so called „DIN joints”, the bearing capacity of the analysed panel set at the axis of the support is determined taking into account only one sheet of metal. This rule does not apply to the joints with double overlap, depicted in Fig. 5a and Fig. 5b. In those cases it is assumed that each sheet increases the total bearing capacity of the joint by $90 \%$ of its ,individual” bearing capacity. As a result the bearing capacity of the combined overlapped cross section at the joint is equal to $180 \%$ of the bearing capacity of a single contributing panel.

\section{PERFORATED AND HOLED PROFILES}

The design rules for sheet metal perforated and holed profiles (with perforations or holes in flanges and/or in webs) are given at point 10.4 of code EN 1993-1-3 [5]. However, this code deals only with the situation when perforations are spaced regularly in the nodes of the equilateral triangular mesh. In order to account for such weakening of the material two substitute thicknesses, i.e. $t_{a, \text { eff }}$ and $t_{b, e f f}$, are introduced to determine the properties of the gross and effective cross section, respectively. The research performed within the framework of „Grispe” and „Grispe Plus” projects allowed to extend these recommendations by appropriate specifications calibrated to the case of often used perforations distributed over a square mesh. A new rule has been developed as well to take into account single (or at most double) circular or square openings in the compressed flange of a profiled sheet. In such case the effective width of the flange is determined by taking into account the cantilevered parts of the considered flange, remaining after the opening has been cut out (Fig. $6)$. 


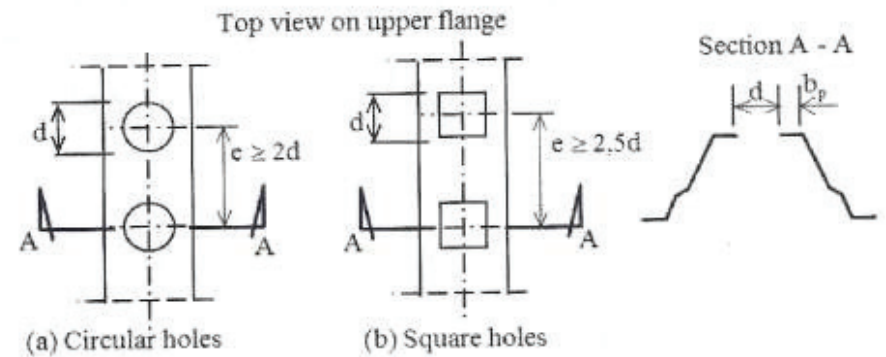

Fig. 6. Compressed flanges of profiled sheet with doubled circular or rectangular cutouts. At right the rule to determine the effective cross section.

\section{EXTERNAL INTERLOCKING PLANKS AND THEIR ASSEMBLIES}

An algorithm to verify the bearing capacity of the planks interlocking by a chevron or clip lock (Fig. 7) constitutes another example of a new computational procedure developed within the framework of „Grispe” and „Grispe Plus” projects. The locks of this type are nowadays gaining popularity because of aesthetical considerations, as they allow for hiding the fixings and creating large unbroken flat surfaces. In the proposed approach the individual panels are treated as the liner trays of a peculiar type, and based on that assumption appropriate verification formulae are used [1], [2]. This approach is accompanied by additional verification of the locked joint against dislocation and complete falling out of a panel. This failure mode is usually related to the wind suction.

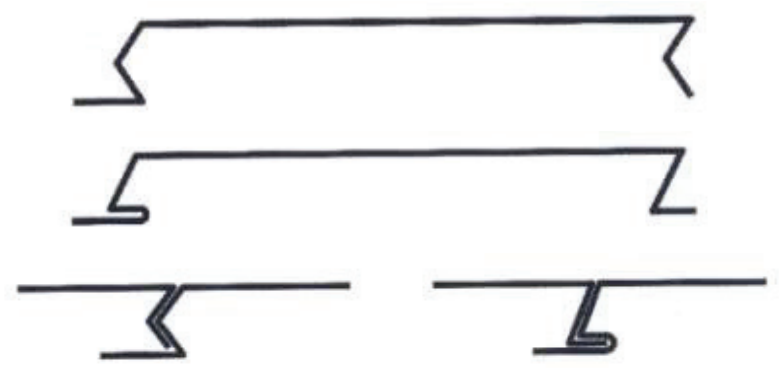

Fig. 7. Complementary interlocking planks, at the top - fitted out with chevron joint, in the middle - fitted out with clip joint, at the bottom - examples of the locked chevron and clip joints. 


\section{CONCLUDING REMARKS}

This article, out of necessity presenting only a brief summary of the new calculation procedures developed within the framework of the „Grispe” and „Grispe Plus” projects, is one of several such studies (for example [10] and [11]) intended for publication in order to popularize the obtained results in the environment of practicing engineers, especially those who in their activities deal with the production and use of thin-walled panels made of profiled steel sheets. A summary of these papers is included in the final report summarizing the „Grispe Plus” project, recently approved by the relevant bodies of the European Union. These papers will be published and distributed in each of the countries participating in both projects listed in the title. Of course, practical application of the developed algorithms requires a more detailed familiarization with the recommended solutions. We hope, that the reports [1] and [2] cited above will prove to be usefull for this purpose. We also count upon that particular procedures submitted to $\mathrm{CEN}$ as proposals for approval and inclusion into the presently used Eurocodes will find their way into the new versions of these codes currently under development.

\section{REFERENCES}

[1] M. Maślak (Ed.), "Projektowanie z wykorzystaniem wybranych stalowych profili cienkościennych - procedury opracowane w ramach projektu "Grispe Plus" - Tom 1: Prezentacje", druk i oprawa - Wydawnictwo PiT, Politechnika Krakowska, Kraków, 2018.

[2] M. Maślak (Ed.), "Projektowanie z wykorzystaniem wybranych stalowych profili cienkościennych - procedury opracowane w ramach projektu "Grispe Plus" - Tom 2: Instrukcje projektowania", druk i oprawa Wydawnictwo PiT, Politechnika Krakowska, Kraków, 2018.

[3] M. Maślak, "Seminarium naukowe w Politechnice Krakowskiej w ramach międzynarodowego projektu badawczego „Grispe Plus””, Inżynieria i Budownictwo, 10: 550, 2018.

[4] EN 1994-1-1: Eurocode 4: Design of composite steel and concrete structures - Part 1.1: General rules and rules for buildings.

[5] EN 1993-1-3: Eurocode 3: Design of steel structures - Part 1-3: General rules - Supplementary rules for coldformed members and sheeting.

[6] StBK-N5: Swedish code for light gauge metal structures, 1982

[7] EN 1993-4-1: Eurocode 3: Design of steel structures - Part 4-1: Silos.

[8] DIN 18807-1 - 1987-06: Trapezprofile im Hochbau; Stahltrapezprofile; Algemeine Anforderungen; Ermittlung der Tragfähigketswerte durch Berechnung, 1987.

[9] DIN 18807-3 - 1987-06: Trapezprofile im Hochbau; Stahltrapezprofile; Festigkeitsnachweis und konstruktive Ausbildung, 1987.

[10] Ch. Fauth, R. Holz, D. C. Ruff, T. Ummenhofer, "Neue Berechnungsverfahren für dünnwandige Stahlprofiltafeln - Ergebnisse aus dem europäischen Forschungsprojekt GRISPE”, Stahlbau, 86, Heft 10, 880889, 2017.

[11] M. Kuhnhenne, D. Pyschny, L. Kramer, M. Brieden, T. Ummenhofer, D. C. Ruff, Ch. Fauth, R. Holz, "Mechanical and thermal performance of new liner tray solutions", Steel Construction, 12, 1, 23-30, 2019. 


\section{LIST OF FIGURES AND TABLES:}

Fig. 1. Profiled sheet metal panel with additional local stiffening of the walls, including: a) longitudinal indentations at left, circular embossments at right, b) dovetail shaped outwards stiffeners.

Rys. 1. Profilowana blacha stalowa $\mathrm{z}$ dodatkowymi lokalnymi usztywnieniami ścianek, $\mathrm{w}$ tym: a) ukształtowanymi $\mathrm{w}$ formie przetłoczeń, $\mathrm{z}$ lewej podłużnych, z prawej okrągłych, b) uformowanymi na kształt jaskółczego ogona.

Fig. 2. Typical lightweight cladding systems using liner trays. Location of fixing distance $s_{1}$ on flanges of a single tray at right.

Rys. 2. Typowe systemy lekkiej obudowy z wykorzystaniem kaset ściennych. Z prawej lokalizacja rozstawu $s_{1}$ na kołnierzach pojedynczej kasety.

Fig. 3. Characteristics of the corrugated panel cross section.

Rys. 3. Charakterystyki przekroju poprzecznego blachy falistej.

Fig. 4. Single overlap profiled steel sheets joint (the so called „DIN joints”), including: a) joint with cantilevered end of profile on top, b) joint with cantilevered end of profile underneath.

Rys. 4. Połączenia arkuszy blach na zakładkę jednostronną (tak zwane „DIN joints”), w tym: a) połączenie ze wspornikowym końcem arkusza na wierzchu, b) połączenie ze wspornikowym końcem arkusza na spodzie.

Fig. 5. Double overlap and local reinforcement steel sheet joints, including: a) double overlap joint, b) continuous profile with local reinforcement.

Rys. 5. Połączenia arkuszy blach na zakładkę dwustronną i z dodatkową nakładką stanowiącą lokalne wzmocnienie, w tym: a) połączenie na zakładkę dwustronną, b) połączenie z uciąglającą nakładką stanowiącą lokalne wzmocnienie.

Fig. 6. Compressed flanges of profiled sheet with doubled circular or rectangular cutouts. At right the rule to determine the effective cross section.

Rys. 6. Ściskane pasy arkusza blachy profilowanej z wyciętymi podwojonymi otworami, okrągłymi lub kwadratowymi. Z prawej zasada wyznaczania przekroju efektywnego.

Fig. 7. Complementary interlocking planks, at the top - fitted out with chevron joint, in the middle - fitted out with clip joint, at the bottom - examples of the locked chevron and clip joints.

Rys. 7. Komplementarne panele linearne, u góry - ze złączem typu szewron, w środku - ze złączem typu klip, na dole - przykłady zamkniętego zamka szewron - klip. 


\section{PROJEKTOWANIE Z UŻYCIEM SPECJALNIE PROFILOWANYCH ARKUSZY BLACH STALOWYCH - PROCEDURY OPRACOWANE W RAMACH PROJEKTÓW GRISPE I GRISPE PLUS}

Stowa kluczowe: cienkościenne profile z blach stalowych, poprawki i uzupełnienia do norm, nośność na zginanie, odporność na deformacje, zestawy profili, przetłoczenia podłużne i/lub okrągłe, otwory i/lub perforacja, samozamykające się zamki.

\section{STRESZCZENIE:}

Na tle krótkiej charakterystyki zakończonego z końcem 2018 roku międzynarodowego projektu badawczego "Grispe Plus”, w którym czynny udział brała Politechnika Krakowska, a także poprzedzającego ten projekt projektu "Grispe", przedstawiono podstawowe założenia nowo opracowanych procedur obliczeniowych dotyczących siedmiu klas cienkościennych elementów konstrukcyjnych wykonanych z użyciem specjalnie kształtowanych paneli stalowych blach profilowanych. Tego typu elementy są jak dotąd słabo obecne w normalizacji, co sprawia że nie opracowano odniesionych do nich jednoznacznych zasad i wymogów projektowania. Są one jednak w nowoczesnym budownictwie powszechnie stosowane w praktyce, zwłaszcza przy kształtowaniu coraz bardziej udoskonalanych zestawów lekkiej obudowy, a ich wykorzystanie wymuszają nie tylko względy estetyczne i użytkowe ale także, a może przede wszystkim, kalkulacja ekonomiczna. Prezentowane założenia oraz opracowane na ich podstawie algorytmy obliczeniowe dotyczą kolejno: paneli wykonanych z blach profilowanych, o ściankach lokalnie usztywnionych przetłoczeniami, podłużnymi lub okrągłymi; analogicznych paneli z zewnętrznym podłużnym usztywnieniem pasów kształtowanym w formie jaskółczego ogona; kaset ściennych z szerszym niż to zastrzeżono w dotychczasowej wersji normy EN 1993-1-3 rozstawem mocowania kołnierzy; przekryć dachowych wykonanych z blachy falistej o sinusoidalnie formowanej fałdzie; paneli łukowych skonstruowanych z blach profilowanych wzdłuż długości łuku; połączeń blach profilowanych wykonanych z zastosowaniem jednostronnej lub dwustronnej zakładki lub też takich, które zrealizowano z użyciem wprowadzonej dodatkowo wkładki wzmacniającej; przekryć z blach profilowanych z perforacją środnika $\mathrm{i} /$ lub pasów, zrealizowaną na regularnej siatce kwadratu; przekryć z blach profilowanych $\mathrm{z}$ pojedynczymi lub co najwyżej podwojonymi otworami w ściskanym pasie, okrągłych albo o kształcie kwadratu, oraz paneli linearnych lekkiej obudowy, łączonych ze sobą na samozazębiające się zamki typu szewron - klip. Każda z proponowanych procedur została opracowana $\mathrm{w}$ formie oficjalnego zgłoszenia wysłanego do CEN z sugestią wprowadzenia odpowiednich korekt lub też ewentualnego uzupełnienia dotychczasowego zakresu obecnie stosowanej normy EN 1993-1-3. Działanie to wpisuje się w szerszą akcję opracowywania nowej generacji eurokodów, wspieraną i finansowaną ze środków Unii Europejskiej.

Procedury wypracowane w ramach przywołanych powyżej projektów badawczych i zaproponowane do powszechnego stosowania dzięki prowadzonym w różnych ośrodkach szeroko zakrojonym kampaniom eksperymentalnym uzyskały odpowiednią weryfikację doświadczalną. Parametry poszczególnych modeli obliczeniowych były dodatkowo kalibrowane numerycznie. Podano również różnego typu ograniczenia warunkujące ich stosowanie w praktyce. Nowo opracowane modele formalne stanowią na ogół rozwinięcie modeli dotychczas stosowanych, zwłaszcza tych opartych na odpowiedniej specyfikacji parametrów przekroju efektywnego, lub też na wykorzystaniu analogii pozwalających na przeniesienie modelu typowego dla weryfikacji danego obiektu na obiekt jakościowo inny, ale o zbliżonej geometrii i podobnym sposobie przenoszenia przyłożonych do niego obciążeń. 
Uczestnicy biorący udział $\mathrm{w}$ obu projektach zobowiązali się do rozpowszechnienia uzyskanych wyników wśród zainteresowanych inżynierów praktyków, a także wśród wytwórców tego typu elementów konstrukcyjnych. W tym celu zorganizowano pięć seminariów poświęconych zagadnieniom raportowanym w niniejszym artykule, po jednym w każdym z krajów biorących udział w projekcie “Grispe Plus”. Jedno z tych seminariów odbyło się w Krakowie, w czerwcu 2018 roku. Opracowano również, z przeznaczeniem dla polskich inżynierów, szczegółowy raport z dokładną prezentacją poszczegółnych procedur obliczeniowych. W drugim tomie tego raportu zawarto prowadzące czytelnika krok po kroku instrukcje projektowania wraz z przykładami obliczeń odniesionych do każdego z rozpatrywanych przypadków. Alternatywną formą upowszechniania wyników uzyskanych w obu projektach jest specjalnie przygotowana strona internetowa www.grispeplus.eu $\mathrm{z}$ odpowiednimi informacjami opracowanymi w językach angielskim, francuskim, niemieckim, włoskim i polskim oraz z dodatkowymi arkuszami kalkulacyjnymi i innymi materiałami ułatwiającymi praktyczne stosowanie proponowanych algorytmów. Niniejsze opracowanie wpisuje się w szerszy zestaw artykułów, publikowanych w różnych krajach lub też, w niektórych przypadkach, dopiero złożonych do ewentualnej publikacji, zestawionych w zatwierdzonym ostatnio przez odpowiednie organy Unii Europejskiej końcowym raporcie z projektu "Grispe Plus” jako te, w których w sposób mniej lub bardziej szczegółowy informuje się o prowadzonych badaniach oraz o wypracowanych na ich podstawie nowych algorytmach obliczeniowych.

Received 26.08.2019

Revised 25.11.2019 